International Research Journal of Management, IT \& Social Sciences
Available online at https://sloap.org/journals/index.php/irjmis/
Vol. 8 No. 2, March 2021, pages: 132-140
$\begin{aligned} & \text { ISSN: 2395-7492 } \\ & \text { https://doi.org/10.21744/irjmis.v8n2.1100 }\end{aligned}$

\title{
The Formative Assessment as Systematic Practice in Higher Basic Education Students
}

\author{
Gema Tatiana Bravo Cobeña ${ }^{a}$ \\ Lucía Atenaida Pin García ${ }^{\mathrm{b}}$ \\ Sandra Cristina Solís Pin ${ }^{\mathrm{c}}$ \\ Lubis Carmita Zambrano Montes ${ }^{\mathrm{d}}$
}

Article history:

Submitted: 27 November 2020

Revised: 09 December 2020

Accepted: 18 January 2021

\section{Keywords: \\ evaluation instruments; \\ formative evaluation; \\ pedagogical practice; \\ student performance; \\ teaching-learning;}

\begin{abstract}
In the educational field, evaluation is a widely used term but generally associated with qualification, measurement, or as a promotional item from year to year. So, it is essential to reflect on the use given to it, in educational contexts. The objective was to analyze the perspective of teachers and students to the formative evaluation and their contribution to the improvement of the teaching-learning process, of the tenth-year students of a Fiscal Educational Unit in the city of Manta. The quantitative method was applied, to gather the information, with the use of a web survey aimed at both. As a result, it was obtained to be applied through: rubrics, portfolios, observations, conceptual maps, essays, co-evaluation, self-assessment, feedback; but, it does so in an ascetic and intuitive way. It is concluded that the assessment must be carried out in a procession manner, where the development of superior skills is enhanced, with dynamic activities, that favor metacognition, and selfregulation in the educational process.
\end{abstract}

International research journal of management, IT and social sciences (C) 2021. This is an open access article under the CC BY-NC-ND license (https://creativecommons.org/licenses/by-nc-nd/4.0/).

Corresponding author:

Gema Tatiana Bravo Cobeña,

Engineer in Hotel Business Administration

Teacher of thePontificia Universidad Católica del Ecuador.

Email address: gbravo9571@pucesm.edu.ec

a Pontificia Universidad Católica del Ecuador, sede Manabí, Portoviejo, Ecuador

b Pontificia Universidad Católica del Ecuador, sede Manabí, Portoviejo, Ecuador

Pontificia Universidad Católica del Ecuador, sede Manabí, Portoviejo, Ecuador

Pontificia Universidad Católica del Ecuador, sede Manabí, Portoviejo, Ecuador 


\section{Introduction}

Educational evaluation should be formative, providing students with the necessary information, to determine their abilities, attitudes, and interests. It is important to know the context in which it is acted and the quality of the teachinglearning processes that are developed. Learning is integrally related to evaluation, so it is given the whole intentionality in the teaching-learning process; one of the biggest errors in education is to confuse evaluation with a rating as directed (Chiappe et al., 2016).

In recent years, the formative assessment approach has made great progress, both at the global, regional, national, and local levels; which has been disseminated through research studies and international congresses, which have helped to clarify the issue and determine that this process is perfected, when significant learnings are regulated and created in students; it also serves to improve teaching activity; as explained in the study of "The formative evaluation in a teaching sequence", carried out in two schools in Segovia-Spain, aimed at sixth graders of primary education (Ortega-Quevedo et al., 2017). In a master's thesis in Education Administration conducted in Peru under the theme "The level of knowledge on formative evaluation in the practice of teaching work of a Secondary Educational Institution of Trujillo", was set as a central objective: to determine the relationship that exists between the level of knowledge on formative evaluation and the technological-methodological practice; it was concluded that most teachers have knowledge about it, but that it must be strengthened with training and accompaniment, to improve the pedagogical work (Rosales-Asmat, 2018).

In the research "The formative evaluation in the performance of students", carried out in Ecuador, a group of teachers and students of the Universidad Laica Eloy Alfaro de Manabí, extension Chone (Saltos- Dueñas \& ChiribogaZambrano, 2016), determined that it serves as a means to raise the quality of the performance of the students and guide the educator; through the adoption of new methodologies, attitudes, techniques, and strategies, which allow to visualize errors and rectify them, with the use of appropriate valuation instruments with a regulation of the number of attendees, to be able to make appropriate decisions in this process as complex as that of teaching-learning (Rao et al., 2011; Higgins \& Reid, 2017; Alcivar et al., 2020). The research aimed to analyze the perspective of teachers and students to the formative evaluation and its contribution to the improvement of the teaching-learning process, in the tenth year students of a Tax Educational Unit in the city of Manta; since, one of the concerns of the current education system, is the lack of understanding and ignorance of the principles and dimensions of it. Based on the findings acquired, it is invited to design proposals that contribute to improving the teaching-learning process.

\section{Materials and Methods}

The research had a qualitative, exploratory-descriptive-non-experimental methodological approach. The analyticalsynthetic scientific method was used. The primary source research technique that was conducted as a web survey, prepared through the evaluation instrument: questionnaire, with open and multiple selection questions, aimed at 10 teachers and 15 students of the tenth year of Basic Education. The results were analyzed, processed, and represented through statistical graphs considering the scientific theories that support them.

\section{Results and Discussions}

\subsection{Formative assessment}

The formative evaluation, allows the student to recognize the extent to which he has understood the educational process, otherwise, the teacher makes the goal understandable and visible; so that it is transformed into an achievement of both. It is important to use appropriate strategies to determine where they are in learning, according to the purposes proposed in students and teachers; for the making of sound decisions, which lead to the advancement of them, and intervene according to the needs of the students in the feedback and make their understanding improve (Pérez Pino et al., 2017). The formative evaluation indicates the student's development concerning training work, whose purpose is to make known their strengths and weaknesses, to improve and determine knowledge. Its main focus is the appreciation of skills and attitudes of the students, to check at what pace it develops and the autonomy that will allow it to solve the problems that arise in daily life. Figure 1 shows the formative evaluation process, which is divided into three moments within the class.

Cobeña, G. T. B., García, L. A. P., Pin, S. C. S., \& Montes, L. C. Z. (2021). The formative assessment as systematic practice in higher basic education students. International Research Journal of Management, IT and Social Sciences, 8(2), 132-140. https://doi.org/10.21744/irjmis.v8n2.1100 

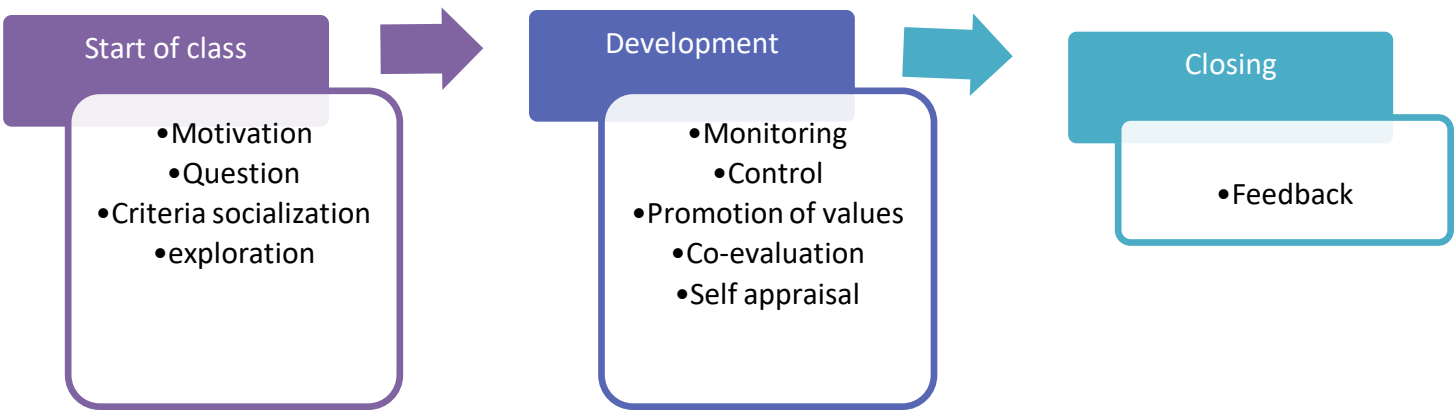

Figure 1. Formative evaluation process

Source: Made from ( Pasek de Pinto \& Mejía, 2017)

\subsection{Formative assessment instruments}

According to Hamodi et al. (2015), the evaluation tools are the tools used by teachers and students to capture in an organized way the information collected by a certain technique.

1) Validity and Reliability and Evaluation Instruments

The validity shows the degree of accuracy with which it is intended to measure the intended objective. Reliability refers to the consistency of its results, implies that the instrument delivers similar products when its application is repeated in the same situations and individuals (Drago, 2017).

Reliability is a necessary means, but not sufficient for validity. One test may be to get a very accurate measure, but something that was not in the interest of evaluating. Therefore, the first thing that must be preserved is authenticity, considering the practice as an educational achievement.

2) Means, techniques, and formative assessment instruments

By conceptualizing these terms, they may be confused with each other, figure 2 explicitly details what the formative assessment instruments are.

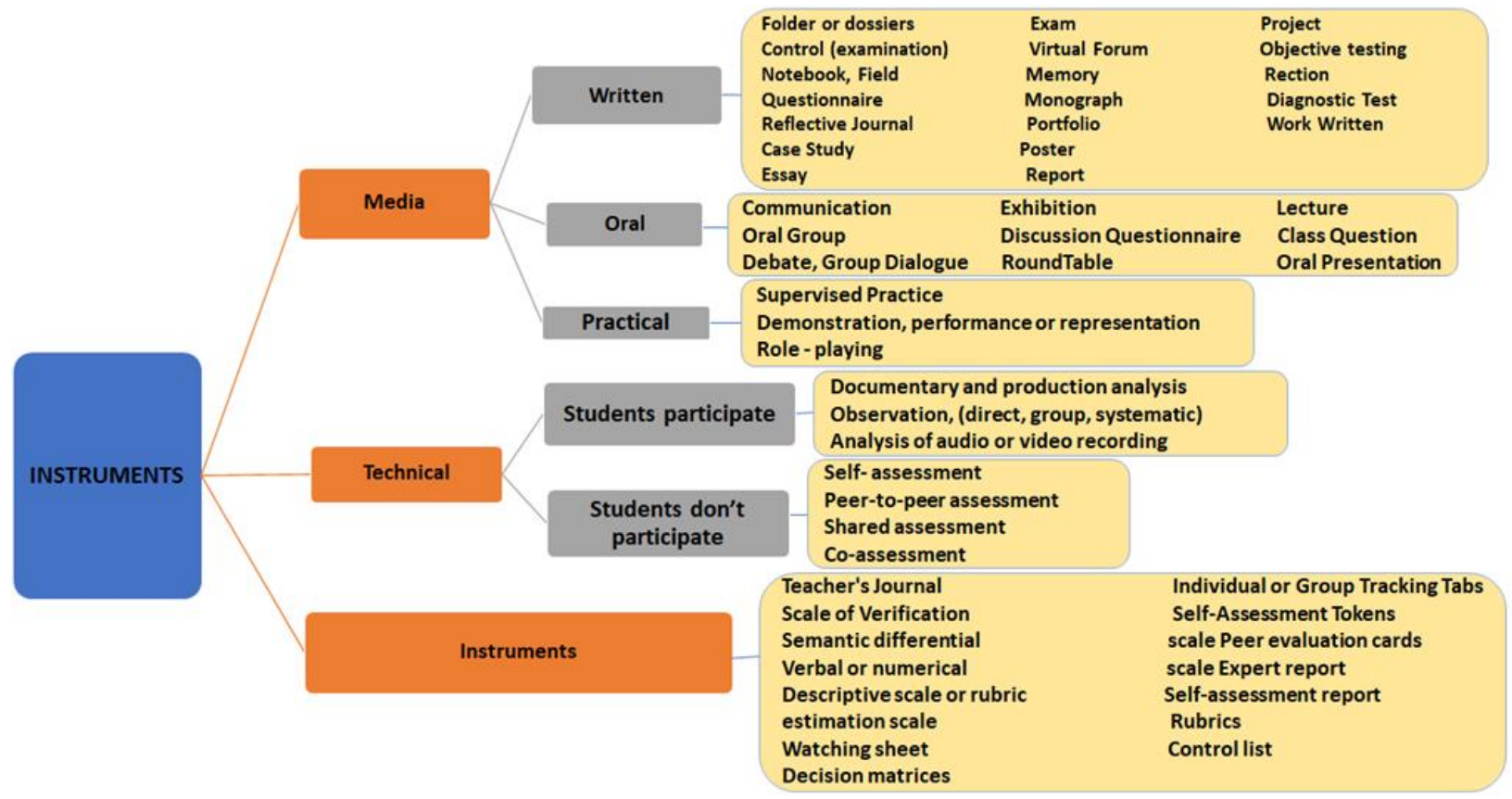

Figure 2. Formative Assessment Instruments

Source: Made from (Hamodi et al., 2015) 
The means can be: written, oral, and practical. The techniques are defined by the participation of the student or nonparticipation of the student; and among the instruments stand out: estimation scales, rubrics, observation sheets, checklists, among others. The most commonly used ones in the educational context are explained below.

1) Estimation scale

It has as its fundamental characteristic the level of concreteness and differentiation in the multiple aspects to be estimated, that is, it is much more meticulous and useful in the teaching-learning process (Pérez-Pueyo \& Carrocera, 2017).

2) Headings

They manage and systematize the evaluative process, facilitate the description of the criteria to follow to appreciate the work done. These are often used to assess different types of products, competencies, and skills acquired by students such as: projects, digital presentations, group work, among others. There are different typologies, but in all cases, they provide certain indicators to document the progress of apprentices. It contains elements to be evaluated and in each of them a description is made, they provide great accuracy to assess the skills and skills acquired by the students, after their training process; through a set of graduated criteria that demonstrate different levels of achievement clearly and explicitly. You can present quantitative and/or qualitative values, so they help teachers describe the criteria (Lezcano \& Vilanova, 2017).

\section{3) E-Portfolios or Portfolios}

Known as a workbook, they reflect instructions through the collection of evidence. This instrument has several applications: it collaborates in the measurement of aspects that are not evaluable through written tests; encourages the student to become aware of their achievements, the learnings achieved and the obstacles that were presented in the process; allow the student to be the protagonist, monitor their progress and difficulties. It is a relatively recent technique, very useful for self-assessment, co-evaluation, and hetero evaluation. (Lezcano \& Vilanova, 2017).

\section{4) Concept maps}

They encourage analysis, understanding of texts, and the distinction of concepts. They are used to obtain a visual representation, of a person's ideas on a particular or priority topic; with a cognitive organization that expresses the relationship between them (Pontes-Pedrajas et al., 2015).

\section{Essay Tests}

The student develops and informs his ideas, based on the reading of a text, a specific topic, or audiovisual material. The student's perception and the degree of argument that he shows in a text (Rapp et al., 2018).

\section{Teaching-learning process}

Education, like any social practice, is complex; has a great challenge today, that the teacher teaches to learn, promoting the student's effort to build learning permanently and innovatively (Cid, 2006). Learning to teach is an intentional process since it aims to modify behaviors, where it influences the very formation of the subject who teaches. One of the main components of the teaching-learning process is the characterization of its objective, without ignoring the systemic nature of it, taking into account the communicative and participatory aspect of the student, which promotes an interrelationship between teachers-students and implies it in the self-regulation of their learning (López \& Mesa, 2016).

\subsection{Formative assessment in pedagogical practice}

The surveys were conducted based on a questionnaire, sent online to both teachers and tenth-year students; the objective set out and the importance of its criteria was explained through audio. Once the data was accepted, tabulation and analysis were carried out. The following figures determine the results. Figure 3 shows the meaning of formative assessment in the educational process.

Cobeña, G. T. B., García, L. A. P., Pin, S. C. S., \& Montes, L. C. Z. (2021). The formative assessment as systematic practice in higher basic education students. International Research Journal of Management, IT and Social Sciences, 8(2), 132-140. https://doi.org/10.21744/irjmis.v8n2.1100 


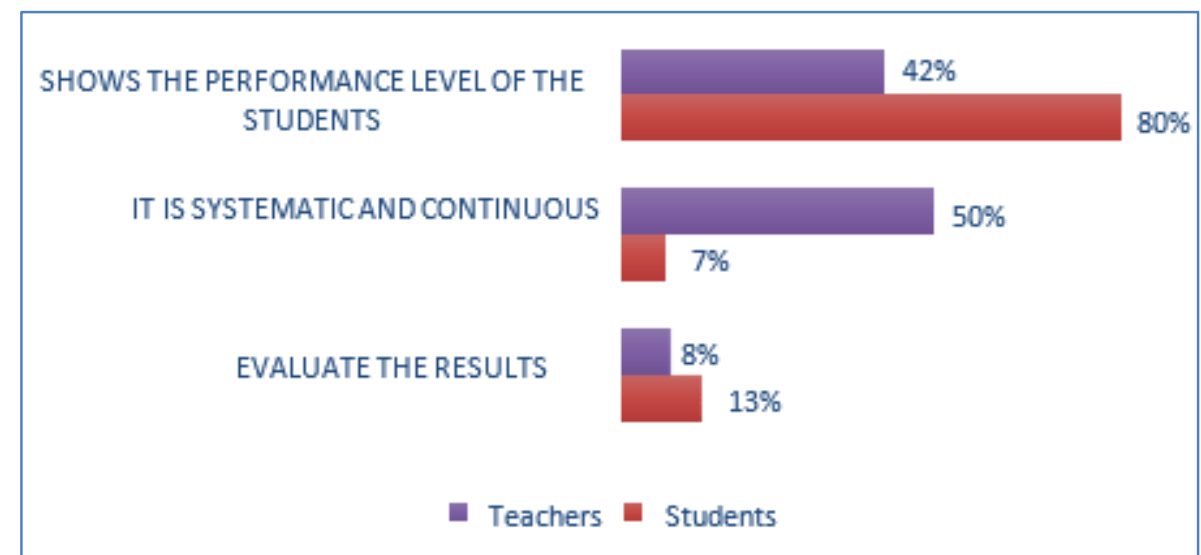

Figure 3. Meaning of Formative Assessment

$80 \%$ of students and $42 \%$ of teachers considered that the formative assessment shows the level of performance of the students; $7 \%$ and $50 \%$ reported that it is systematic and continuous; $8 \%$ and $13 \%$ deduced that the results were evaluated. As directed by a large percentage of respondents, it was interpreted that a large percentage of respondents are directed in a correct conceptualization of formative evaluation as directed (Rosales, 2014; Gillies \& Boyle, 2008; Pursi, 2019), it is the one that is carried out during the development of the teaching-learning process to locate, the deficiencies when they are still in the possibility of remedying them and making the relevant decisions.

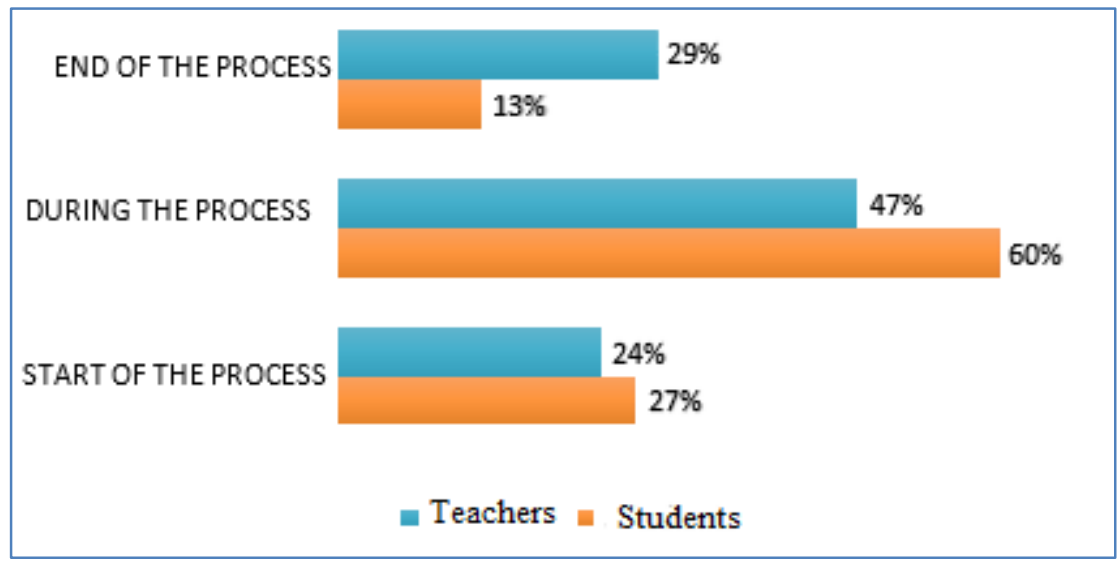

Figure 4. Shows the teaching evaluation moments

$27 \%$ and $24 \%$ of students and teachers respectively reported that they are evaluated at the beginning of the process; $60 \%$ and $47 \%$ indicated that the evaluation was carried out during the process, and $29 \%$ and $13 \%$ concluded that the evaluation was carried out at the end of the process. The criterion issued by (Prieto Castillo, 2015), states that when teachers evaluate, they use the classroom evaluation process and the continuous flow of information about student performance; understanding, articulating, and guiding the achievement of goals; and conducting descriptive feedback. The teacher must specify the procedures and instruments according to the degree to which the changes occur, not only in the last stage but during the process (Navarro Mosquera et al., 2017). Figure 5 provides for the assessment of knowledge, attitudes, skills, and interests manifested in the assessment tools. 


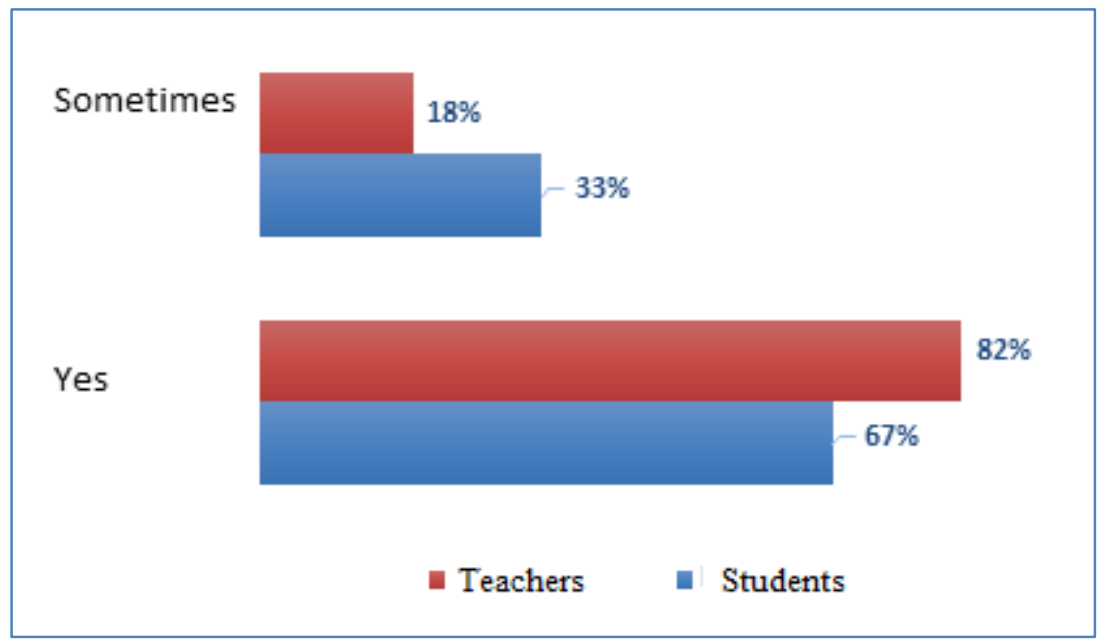

Figure 5. Assessment of knowledge, attitudes, skills, and interests

According to what was observed, $67 \%$ of students and $82 \%$ of teachers revealed that the training assessment tools if they respond to the assessment of their knowledge, attitudes, skills, and interests. $33 \%$ and $18 \%$ of respondents mentioned that sometimes these instruments are in line with the characteristics listed above; none gives negative estimates of this type of evaluation; favoring the development of responsibility, the autonomy of apprentices, the capacity for critical analysis, and the improvement of the teaching process-learning (López-Pastor \& Pérez-Pueyo, 2017). The formative assessment is detailed in Figure 6 as a component for decision-making in the process.

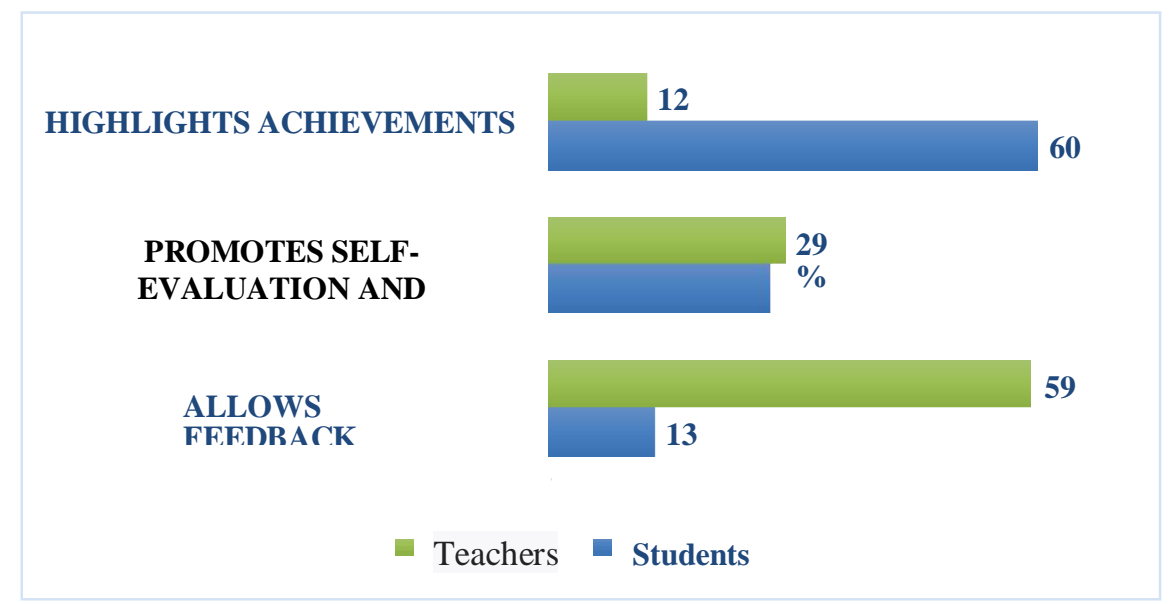

Figure 6. Formative Assessment as a mechanism for decision-making

It was shown that $13 \%$ of students and $59 \%$ of teachers noted that formative evaluation in the process allows feedback; $27 \%$ and $29 \%$ considered self-assessment and co-assessment to be promoted; $60 \%$ and $12 \%$ recorded that the achievements achieved are highlighted. Since formative evaluation helps teachers and students in decision-making focused on improving the teaching-learning process, supported by research and knowledge; generates teaching adjustments in both (Popham, 2013). Co-evaluation promotes autonomy and the use of complex thinking skills, gives personal and collective responsibility, promotes self-management, self-regulation, and tacit positive interdependence in collaboration (Valdivia, 2008). Self-assessment stimulates the student's responsibility for his or her learning process (Lopez, 2010). Feedback should be analyzed from its multidimensionality, with a formative effect, to the apprentice and with a motivating effect (Canabal \& Margalef, 2017). Also, the democratic realm should be considered to obtain positive results in feedback (Lorente-Catalan \& Kirk, 2014).

Cobeña, G. T. B., García, L. A. P., Pin, S. C. S., \& Montes, L. C. Z. (2021). The formative assessment as systematic practice in higher basic education students. International Research Journal of Management, IT and Social Sciences, 8(2), 132-140. https://doi.org/10.21744/irjmis.v8n2.1100 
Figure 7 shows the means and training assessment tools applied to students

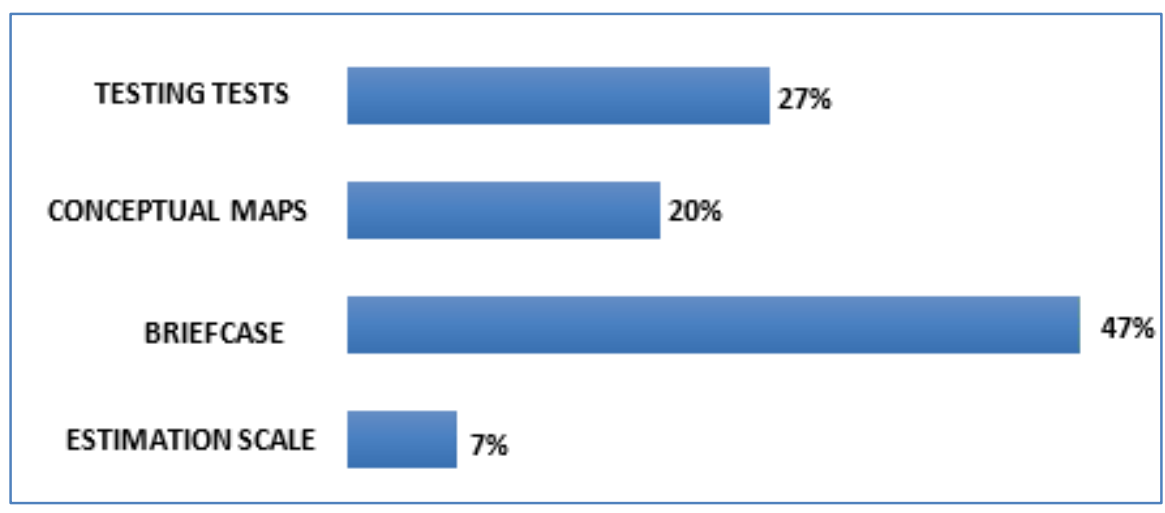

Figure 7. The means and instruments of formative assessment

$7 \%$ of students responded that teachers use scales of estimation or appreciation; $47 \%$ noted that teachers apply portfolios; $20 \%$ use concept maps, and $27 \%$ that apply test tests; they also indicated the non-use of rubrics. It was evident, that the formative evaluation is applied with the use of: portfolios, conceptual maps, essays, estimation scale, which enhance training, but each procedure must have an instrument, to detect how to perform the feedback and determine the acquisition of the process of metacognition of students (Alcalá et al., 2019).

\section{Conclusion}

In the conduct of the research, it was determined that a large percentage of teachers and students address in pedagogical practice the aspects related to means, techniques, and instruments of formative evaluation; but they do not have a clear conceptualization of them; mismos; and in many cases these activities are carried out intuitively, lacking verifiable instruments. Formative evaluation is necessary for decision-making, because it creates opportunities for improvement, puts your knowledge at stake, recognizes the strengths and weaknesses of students and teachers; developing metacognitive skills (Triantafillou et al., 2003; Kordaki, 2010). After all, it provides concrete guidance on how to permanently and continuously correct, leading to significant change.

\section{Conflict of interest statement}

The authors declared that they have no competing interests.

\section{Statement of authorship}

The authors have a responsibility for the conception and design of the study. The authors have approved the final article.

\section{Acknowledgments}

We are grateful to two anonymous reviewers for their valuable comments on the earlier version of this paper. 


\section{References}

Alcalá, DH, Pueyo, Á. P., \& Calvo, GG (2019). But... What do we really mean by Formative and Shared Assessment ?: Habitual Confusions and Practical Reflections. Ibero-American Journal of Educational Evaluation , 12 (1), 13 27.

Alcivar, C. M. M., Quimi, T. L. I., \& Barberan, M. F. Z. (2020). The motivation and its importance in the teachinglearning process. International Research Journal of Management, IT and Social Sciences, 7(1), 138-144.

Canabal, C., \& Margalef, L. (2017). Feedback: the key to a learning-oriented assessment. Faculty. Journal of curriculum and teacher training , 21 (2), 149-170.

Chiappe, A., Pinto, R., \& Arias, V. (2016). Open assessment of learning: A meta-Synthesis. International Review of Research in Open and Distributed Learning: IRRODL, 17(6), 44-61.

Cid, MT (2006). Teach to learn to think in schools, including in evaluation activities. Interuniversity electronic journal of teacher training , 9 (1), 1-14.

Drago, C. (2017). Manual de apoyo docente: evaluación para el aprendizaje. Santiago de Chile: Editorial Universidad Central de Chile.

Gillies, R. M., \& Boyle, M. (2008). Teachers' discourse during cooperative learning and their perceptions of this pedagogical practice. Teaching and Teacher Education, 24(5), 1333-1348. https://doi.org/10.1016/j.tate.2007.10.003

Hamodi, C., López Pastor, VM, \& López Pastor, AT (2015). Means, techniques and instruments of formative and shared evaluation of learning in higher education. Educational Profiles, 37 (147), 146-161.

Higgins, B., \& Reid, H. (2017). Enhancing “conceptual teaching/learning” in a concept-based curriculum. Teaching and Learning in Nursing, 12(2), 95-102. https://doi.org/10.1016/j.teln.2016.10.005

Kordaki, M. (2010). A drawing and multi-representational computer environment for beginners' learning of programming using C: Design and pilot formative evaluation. Computers \& Education, 54(1), 69-87. https://doi.org/10.1016/j.compedu.2009.07.012

Lezcano, L., \& Vilanova, G. (2017). Learning assessment instruments in virtual environments. Student perspective and teacher contributions. Technical Scientific Reports-UNPA , 9 (1), 1-36.

López Pastor, VM, \& Pérez Pueyo, Á. (2017). Formative and shared evaluation in education: successful experiences in all educational stages . León: University of León, 2017.

López, AA (2010). Formative assessment in the teaching and learning of English. voices and silences. Latin American Journal of Education , 1 (2), 111-124.

López, GB, \& Mesa, MC (2016). The teaching-learning process from a communicative perspective. Ibero-American Journal of Education , 1-7.

Lorente-Catalán, E., \& Kirk, D. (2014). Making the case for democratic assessment practices within a critical pedagogy of physical education teacher education. European Physical Education Review, 20(1), 104-119.

Navarro Mosquera, NG, Falconí Asanza, AV, \& Espinoza Cordero, J. (2017). The improvement of the evaluation process for students in basic education. University and Society Magazine, 9 (4), 58-69.

Ortega-Quevedo, V., Santamaría-Cárdaba, N., \& Puente, CG (2017). The formative evaluation in a teaching-learning sequence of Experimental Sciences. Revista Infancia, Educación y Aprendizaje , 3 (2), 203-209.

Pasek de Pinto, E., \& Mejía, MT (2017). General process for formative assessment of learning. Ibero-American Journal of Educational Evaluation .

Pérez Pino, M., Enrique Clavero, JO, Carbó Ayala, JE, \& González Falcón, M. (2017). Formative evaluation in the teaching-learning process. Edumecentro , 9 (3), 263-283.

Pérez-Pueyo, Á., \& Carrocera, MS (2017). Development of instruments (assessment and graduated scales) for formative assessment. Revista Infancia, Educación y Aprendizaje , 3 (2), 808-814.

Pontes-Pedrajas, A., Serrano Rodríguez, R., \& Muñoz González, JM (2015). Concept maps as a resource of interest for the initial training of Secondary Education teachers: Opinions of the students of Social Sciences and Humanities.

Popham, WJ (2013). Transformative evaluation: the transformative power of formative evaluation (Vol. 124). Narcea Editions.

Prieto Castillo, D. (2015). In praise of university pedagogy.

Pursi, A. (2019). Play in adult-child interaction: Institutional multi-party interaction and pedagogical practice in a toddler classroom. Learning, Culture and Social Interaction, 21, 136-150. https://doi.org/10.1016/j.lcsi.2019.02.014

Cobeña, G. T. B., García, L. A. P., Pin, S. C. S., \& Montes, L. C. Z. (2021). The formative assessment as systematic practice in higher basic education students. International Research Journal of Management, IT and Social Sciences, 8(2), 132-140. https://doi.org/10.21744/irjmis.v8n2.1100 
Rao, R. V., Savsani, V. J., \& Vakharia, D. P. (2011). Teaching-learning-based optimization: a novel method for constrained mechanical design optimization problems. Computer-Aided Design, 43(3), 303-315. https://doi.org/10.1016/j.cad.2010.12.015

Rosales Asmat, MS (2018). The level of knowledge about formative evaluation in the practice of teaching in a Secondary Educational Institution of Trujillo, 2017.

Rosales, M. (2014). Evaluation process: summative evaluation, formative evaluation and assessment of its impact on current education. In Ibero-American Congress of Science, Technology, Innovation and Education (Vol. 4, p. 662).

Saltos-Dueñas, CML, \& Chiriboga-Zambrano, MJ (2016). The formative evaluation in the performance of the students. Science Domain , 2 (4), 112-127.

Triantafillou, E., Pomportsis, A., \& Demetriadis, S. (2003). The design and the formative evaluation of an adaptive educational system based on cognitive styles. Computers \& Education, 41(1), 87-103. https://doi.org/10.1016/S0360-1315(03)00031-9

Valdivia, I. Á. (2008). Co-evaluation as an alternative to improve the quality of learning of university students: assessment of an experience. Interuniversity journal of teacher training, 22 (3), 127-140.

Vallés Rapp, C., Martínez Mínguez, L., \& Romero Martín, MDR (2018). Assessment instruments: Use and competence of university teaching staff in their application. Pedagogical Studies (Valdivia), 44 (2), 149-169. 